\title{
CORRELATION BETWEEN SUSCEPTIBILITY TO FUSARIUM WILT AND AGRONOMIC AND TECHNOLOGICAL TRAITS IN SOME COTTON GENOTYPES

\author{
Aly, A.A. ${ }^{1}$; Hanan M. Abd El-Gelil'; A M.A. El-Samawaty ${ }^{1}$ and \\ E.M. Hussein ${ }^{1}$ \\ 1.Plant Pathology Research Institute, Agricultural Research Center, \\ Giza, Egypt. \\ 2. Cotton Research Institute, Agricultural Research Center, Giza, Egypt.
}

\begin{abstract}
Field trials were carried out at Giza Agricultural Research Station in 2012 and 2013 growing seasons. In 2012, 50 cotton genotypes were self-pollinated. In 2013, the genotypes were grown in a randomized complete block design with thre replications. A random sample of four guarded plants of each genotype was randomly chosen from each plot to determine some agronomic and technological traits. The agronomic traits were boll weight $(\mathrm{g})$, seedcotton yield (g/plant), lint yield (g/plant), and lint percentage. The technological traits were fiber length at $2.5 \%(\mathrm{~mm})$, fiber length uniformity ratio (\%), micronaire reading and fiber strength $(\mathrm{g} / \mathrm{tex})$. The genotypes were screened, under greenhouse conditions, in 2014 against a mixture of 50 isolates (race 3 ) of the wilt fungus. Incidence of Fusarium wilt was used as criterion to evaluate the reactions of the tested genotypes to the disease. The genotypes showed a narrow range of reactions to Fusarium wilt incidence ranging from 0 to $19.99 \%$. Of the tested genotypes, 54, 40 and $6 \%$ were classified as highly resistant (wilt incidence was $0 \%$ ) resistant (wilt incidence ranged from 3.33 to $6.66 \%$ ), and susceptible (wilt incidence ranged from 13.33 to $19.99 \%$ ), respectively. Linear correlation coefficient was calculated to measure the degree of association between wilt incidence and each of agronomic and technological traits. Cluster analysis was used for grouping the genotypes based on the profiles of their agronomic and technological traits. Correlation and cluster analysis showed a lack of correlation between wilt incidence and each of agronomic and technological traits. This result suggests that breeding for Fusarium wilt resistance in cotton will not negatively affect the quality of agronomic or technological traits.
\end{abstract}

Keywords: Egyptian cotton, Fusarium wilt resistance, agronomic, and technological traits.

\section{INTRODUCTION}

Fusarium wilt of cotton is a serious fungal disease responsible for significant losses throughout the world. The causal organism Fusarium oxysporum Schlecht. f.sp. vasinfectum (ATK.) Snyd and Hans. (FOV) invades the host through the taproots behind the root tip. The combined effect of fungal metabolites and the production of lipodial substances by the host in response to infection may lead to occlusion of the vascular tissue, resulting in wilt of the cotton plant (Hillocks, 1984). FOV can survive for several decades in soil and cannot be eradicated from infested fields. The pathogen can infected cotton at all stages of growth and produces symptoms, which include seedling death, wilting, vascular discolouration and plant death (Watkins, 1981). 
Outside Egypt, it is commonly associated with nematode infection [root knot- Fusarium wilt complex (McFadden et al., 2004)], particularly in acidic, sandy soils. In Egypt, where cotton is grown in alkaline clay soils, there is no evidence for the involvement of nematodes in Fusarium wilt disease (A.A. Aly, personal observation).

Currently, up to eight races of FOV, most of which are geographically separated, are recognized worldwide. The basis for determining races of FOV depends on their virulence to a differential set of cotton (Gossypium) lines and species and up to 5 non-cotton hosts (Watkins, 1981).

The Egyptian race (race 3 ) of FOV, has long been known in the Nile Valley, where it remains one of the most damaging pathogens on Egyption Cotfons ( $G$. barbadense L.). This race also attacks $G$. barbadense in the former, Soviet Union (Watkins, 1981) and Israel (Netzer et al., 1985).

FOV caused serious losses in the commercial Egyptian cottons ( $G$. barbadense L.) in the late fifties (Bakry et al., 1958). Since then, an extensive cotton-breeding program was initiated to develop cultivars resistant to the disease. In this program, breeding materials submitted by cotton breeders (Cotton Research Institute) have been screened for Fusarium wilt resistance under greenhouse conditions in soil artificially infested with FOV. This test has been conducted annually for the past 60 years in the greenhouses of Cotton and Fiber Crops Dis. Res. Section, Plant Pathology Research Institute. The program has been so successful in developing highly resistant commercial cultivars that the disease no longer occurs in the commercial fields (Aly et al., 2000).

Fusarium wilt remains a potential threat to cotton production in Egypt because FOV is still well established in the Egyptian soil (Aly et al., 2000)., thus, increasing the probability that new races other than race 3 or new biotypes of this race may arise to confound cotton breeders.

Cotton fiber is defined by a suite of traits, which have a major impact on fiber selling price. Several fiber quality parameters such as fiber length, length uniformity, strength, and elongation are genetically controlled, mainly but other traits like micronaire, though genetically controlled, are impacted, to a greater degree by environmental conditions (Baxevanos et al., 2013).

Outside Egypt, few attempts have been made to evaluate the correlation between incidence of Fusarium wilt and each of agronomic and technological traits. For example, in China, Wu et al. (2004) found that incidence grade of Fusarium wilt was negatively correlated with fiber strength, micronaire value, and the fiber span length, and reached significant and highly significant levels. In USA, Ulloa et al. (2006) reported that foliar damage and vascular discolouration caused by FOV were negatively correlated with node number and plant height. In China, Guo et al. (2013) found that oil content in cottonseed Kernels was weakly negatively correlated with Fusarium wilt resistance. Thus, the improvement of the oil content of cottonseed kernels will weakly affect disease resistance.

In Egypt, as far as we know, no attempts have been made to study the correlation between incidence of Fusarium wilt and each of agronomic and technological traits. Therefore, the objectives of the present study were to evaluate a collection of cotton germplasm against Fusarium wilt race 3 and 
to evaluate the correlation between wilt incidence on the tested genotypes and their agronomic and technological traits.

\section{MATERIALS AND METHODS}

\section{Cotton genotypes:}

The genotypes used in the present study were randomly selected from the collection of germplasm available at the Department of Cotton Breeding, Cytology and Genetics Unit, Cotton Research Institute (Table 1).

\section{Field traits:}

Field traits were carried out at Giza Agricultural Research Station in 2012 and 2013 growing seasons. In 2012 growing season, cotton genotypes were self- pollinated. In 2013 growing season, they were grown in a randomized complete block design with three replications. Each plot consisted of two rows, the row was six meter long, $60 \mathrm{~cm}$ apart and interhill spacing was $20 \mathrm{~cm}$. Seedlings were thinned to one seedling per hill. The recommended cultural practices were adopted throughout the growing season. A random sample of four guarded plants of each genotype was chosen from each plot to determine the following traits (Said et al., 2013).

\section{a. Agronomic traits:}

1. Boll weight (BW): The average weight in grams of a boll calculated from a random sample of five harvested bolls / plant.

2. Seedcotton yield (SCY): The expression of seedcotton weight in grams / plant.

3. Lint yield (LY): The expression of lint weight in grams / plant.

4. Lint percentage $(L \%)$ : The ratio by weight of lint to seedcotton.

Agronomic traits of the tested genotypes are shown in Table 2.

b. Technological traits:

1. Fiber length at $2.5 \%(\mathrm{~mm})$ : The upper half mean length. It was measured by a fibrograph according to ASTM: D 1447-83 (1984).

2. Fiber length uniformity ratio (\%): The expression of the ratio of upper-half fiber length and the mean length. It was determined according to Sundaram (1979).

3. Micronaire reading: The measurement of fiber fineness and maturity. It was determined according to ASTM: D 1448 - 59 (1984).

4. Fiber strength ( $\mathrm{g} / \mathrm{tex}$ ): The necessary force to break a beard of fibers that are clamped between two sets of jaws. It was determined according to ASTM: D 1448- 59 (1984).

All fiber test were carried out in the Laboratories of Cotton Research Institute, Agric. Res. Center, Giza at constant relative humidity of $65 \pm 2 \%$ and temperature of $70 \pm 20$ of. Technological traits of the tested genotypes are shown in Table 3. 
Aly, A.A. et al.

Table 1. Cotton genotypes used in the present study.

\begin{tabular}{|c|c|}
\hline $\begin{array}{c}\text { Genotype } \\
\text { Number }\end{array}$ & Pedigree \\
\hline 1 & Giza 69 / 92 \\
\hline 2 & Giza 70 / 93 \\
\hline 3 & Giza 81/ 94 \\
\hline 4 & Giza 85 / 96 \\
\hline 5 & Giza $86 / 98$ \\
\hline 6 & Australian 10229 / 101 \\
\hline 7 & (Giza 81 x Giza 86) / 106 \\
\hline 8 & (Giza 85 x Giza 89) / 107 \\
\hline 9 & (Giza 86 x Giza 85 x Giza 89) / 115 \\
\hline 10 & (Pima S) 2 / 127 \\
\hline 11 & Giza 67 / 128 \\
\hline 12 & $($ Pima S x Giza 85) / 129 \\
\hline 13 & (Aamon x Giza 89) / 130 \\
\hline 14 & $\left(\right.$ Pima S $_{7} \times$ Giza 67) / 131 \\
\hline 15 & Bahteem / 142 \\
\hline 16 & Giza 84 / 144 \\
\hline 17 & Giza $70 / 145$ \\
\hline 18 & Giza $87 / 146$ \\
\hline 19 & Giza 74 / 148 \\
\hline 20 & Giza 45 / 149 \\
\hline 21 & $($ Giza 77 x Giza 81) / 150 \\
\hline 22 & (Giza 70 x Giza 77 x Giza 87) / 153 \\
\hline 23 & $($ Giza 70 x Giza 84) / 155 \\
\hline 24 & $\left(\right.$ Pima S $_{6} \times$ Giza 77) / 162 \\
\hline 25 & $($ Giza 74 x Giza 71) / 163 \\
\hline 26 & (Giza 70 x Giza 77) / 164 \\
\hline 27 & $($ Giza 45 x Giza 68) / 165 \\
\hline 28 & Giza $88 / 167$ \\
\hline 29 & Giza 45 / 169 \\
\hline 30 & Giza 68 / 171 \\
\hline 31 & Giza $71 / 172$ \\
\hline 32 & Karnak / 175 \\
\hline 33 & $($ Giza 86 x Giza 84) / 176 \\
\hline 34 & (Giza 45 x Giza 70) / 177 \\
\hline 35 & $($ Giza 77 x Giza 76) / 178 \\
\hline 36 & $($ Giza 77 x Giza 45) / 179 \\
\hline 37 & (Giza 81 x Giza 87) / 180 \\
\hline 38 & Pima S 6 x Giza 45) / 181 \\
\hline 39 & $($ Giza 77 x Giza 74)/ 182 \\
\hline 40 & Pima S $_{6} \times$ Giza 70) / 183 \\
\hline 41 & Giza 84 x (Giza 45 x Giza 84) / 184 \\
\hline 42 & Giza 77 x (Giza 77 x Giza 84) / 185 \\
\hline 43 & (Giza 86 x Giza 74) x Giza 84 / 187 \\
\hline 44 & (Giza 45xGiza 77)x(Giza 51 B x Giza 70) / 189 \\
\hline 45 & (Pima S x Giza 45) x (Giza 45 x Giza 68) / 190 \\
\hline 46 & Giza 45 (Radiated) / 192 \\
\hline 47 & Giza $76 / 193$ \\
\hline 48 & (Giza 77 x Giza 84) / 193 \\
\hline 49 & $\left(\right.$ Pima S $_{6} \times$ Giza 87) / 199 \\
\hline 50 & (Giza 74 x Giza 71) x Giza 77 / 202 \\
\hline
\end{tabular}


Table 2. Agronomic traits of genotypes used in the present study.

\begin{tabular}{|c|c|c|c|c|}
\hline $\begin{array}{c}\text { Genotype } \\
\text { Number. }\end{array}$ & Boll weight $\mathbf{( g )}$ & $\begin{array}{c}\text { Seedcotton yield } \\
\text { (g/ plant) }\end{array}$ & $\begin{array}{c}\text { Lint yield } \\
\text { (g/ plant) }\end{array}$ & Lint percentage \\
\hline 1 & 2.80 & 27.83 & 7.73 & 34.15 \\
\hline 2 & 2.63 & 25.10 & 8.80 & 34.08 \\
\hline 3 & 2.08 & 13.93 & 4.80 & 35.88 \\
\hline 4 & 2.43 & 13.70 & 4.60 & 34.25 \\
\hline 5 & 2.33 & 32.05 & 11.35 & 36.35 \\
\hline 6 & 2.28 & 9.48 & 3.63 & 37.15 \\
\hline 7 & 2.30 & 7.53 & 2.85 & 38.15 \\
\hline 8 & 2.43 & 11.08 & 4.25 & 38.43 \\
\hline 9 & 2.58 & 20.55 & 6.73 & 35.65 \\
\hline 10 & 2.43 & 30.40 & 10.33 & 34.73 \\
\hline 11 & 2.88 & 26.40 & 9.53 & 36.58 \\
\hline 12 & 2.98 & 19.50 & 6.93 & 35.80 \\
\hline 13 & 2.80 & 15.25 & 5.63 & 36.93 \\
\hline 14 & 2.75 & 16.43 & 6.05 & 37.10 \\
\hline 15 & 2.65 & 34.00 & 11.43 & 33.15 \\
\hline 16 & 2.33 & 8.53 & 2.65 & 31.40 \\
\hline 17 & 2.45 & 11.70 & 3.55 & 30.60 \\
\hline 18 & 2.25 & 10.40 & 3.10 & 30.00 \\
\hline 19 & 2.80 & 11.23 & 3.63 & 32.33 \\
\hline 20 & 2.55 & 22.88 & 7.48 & 32.45 \\
\hline 21 & 2.33 & 16.80 & 5.48 & 32.48 \\
\hline 22 & 2.48 & 65.80 & 6.63 & 31.53 \\
\hline 23 & 2.43 & 13.33 & 4.55 & 34.25 \\
\hline 24 & 2.43 & 12.80 & 4.05 & 31.88 \\
\hline 25 & 2.73 & 7.60 & 2.53 & 33.70 \\
\hline
\end{tabular}

Evaluation of cotton germplasm against Fusarium wilt race 3 under greenhouse conditions:

The fungal inoculum used in the greenhouse test was a mixture of equal parts $(w / w)$ of 50 isolates of FOV race 3 . These isolates were obtained from the fungal collection of Cotton Pathology Lab., Plant Pathology Res. Inst., Agric. Res. Center., Giza. Autoclaved clay loam soil was infested with the mixture of the isolates at a rate of $10 \mathrm{~g} / \mathrm{Kg}$ of soil. Substrate for growth of each isolate was prepared in $500-\mathrm{ml}$ glass bottles, each bottle contained $50 \mathrm{~g}$ of Sorghum grains and $40 \mathrm{ml}$ of tap water. Contents of the bottle were autoclaved for 30 minutes. Isolate inoculum, taken from one-week old culture on PDA, was aseptically introduced into the bottle and allowed to colonize sorghum for 3 weeks. Infested soil was dispensed in $10-\mathrm{cm}$ diameter clay pots and these were planted with 10 seeds per pot. There were five replications (pots) for each genotype. Pots were distributed on a greenhouse bench in a randomized complete block design of five replications. The greenhouse was equipped with a heating system assuring that the minimum temperature in the greenhouse was maintained at $28^{\circ} \mathrm{C}$; however, due to the lack of a cooling system, the maximum temperature was out of control fluctuating from 30 to $35^{\circ} \mathrm{C}$ depending on the prevailing temperature during the day (the test was conducted in January and February, 2014). 
Aly, A.A. et al.

Table 2. Cont..

\begin{tabular}{|c|c|c|c|c|}
\hline $\begin{array}{c}\text { Genotype } \\
\text { Number. }\end{array}$ & Boll weight $\mathbf{( g )}$ & $\begin{array}{c}\text { Seedcotton yield } \\
\text { (g/ plant) }\end{array}$ & $\begin{array}{c}\text { Lint yield } \\
\text { (g / plant) }\end{array}$ & Lint percentage \\
\hline 26 & 2.60 & 15.35 & 5.25 & 33.85 \\
\hline 27 & 2.30 & 9.20 & 3.25 & 35.45 \\
\hline 28 & 2.48 & 13.23 & 5.43 & 34.35 \\
\hline 29 & 2.50 & 15.00 & 2.85 & 33.51 \\
\hline 30 & 2.25 & 7.25 & 2.03 & 39.30 \\
\hline 31 & 2.25 & 6.05 & 5.05 & 36.90 \\
\hline 32 & 2.83 & 14.63 & 4.73 & 34.50 \\
\hline 33 & 2.90 & 13.50 & 5.70 & 35.13 \\
\hline 34 & 2.73 & 16.90 & 4.23 & 33.90 \\
\hline 35 & 2.48 & 11.33 & 3.25 & 37.35 \\
\hline 36 & 2.43 & 12.83 & 6.38 & 37.25 \\
\hline 37 & 2.48 & 17.68 & 4.50 & 36.05 \\
\hline 38 & 2.43 & 12.50 & 4.30 & 37.25 \\
\hline 39 & 2.60 & 11.63 & 5.85 & 37.10 \\
\hline 40 & 2.53 & 15.68 & 7.25 & 36.43 \\
\hline 41 & 2.68 & 19.78 & 5.98 & 35.83 \\
\hline 42 & 2.68 & 16.63 & 6.03 & 30.93 \\
\hline 43 & 2.60 & 19.30 & 4.15 & 34.90 \\
\hline 44 & 2.20 & 12.10 & 4.55 & 31.28 \\
\hline 45 & 2.48 & 14.53 & 4.80 & 32.45 \\
\hline 46 & 2.63 & 14.98 & 6.05 & 33.05 \\
\hline 47 & 3.10 & 17.63 & 4.23 & 36.83 \\
\hline 48 & 2.60 & 25.08 & 2.83 & 33.20 \\
\hline 49 & 2.70 & 11.48 & & \\
\hline 50 & 2.93 & 8.63 & & \\
\hline
\end{tabular}

Assessment of Fusarium wilt incidence:

Percentages of infected seedlings were recorded 45 days from planting date. The infected seedlings included the dead seedlings and the surviving seedlings, which showed external or internal symptoms. The external symptoms usually began at the margin of cotyledons as yellowing along the veins (vein clearing), eventually, the entire cotyledons turned yellow and dropped from the seedlings. Seedlings that remained apparently healthy 45 days after planting were cut diagonally across the root and stem to examine the internal symptoms. If discolouration of xylem vessels was observed, they were considered infected. If seedlings were free of such a discolouration, they were considered healthy. Thus, the seedlings of each genotype were placed in two distinct classes: healthy if they were free of any external or internal symptoms, or infected if the seedlings died or survived showing any external or internal symptoms (Aly et al., 2007 and Abd-Elsalam et al., 2009).

Wilt incidence on the tested genotypes is shown in Table 4.

Statistical analysis of the data:

Linear correlation coefficient was calculated to measure the degree of association between wilt incidence and each of agronomic and technological traits. Genotypes were clustered by the average linked technique (unweighted pair-group method) based on the profiles of their agronomic and technological traits. Correlation and cluster analyses were performed with the software package SPSS 6.0. 
Table 3. Technological traits of genotypes used in the present study.

\begin{tabular}{|c|c|c|c|c|}
\hline $\begin{array}{l}\text { Genotype } \\
\text { Number. }\end{array}$ & $\begin{array}{c}\text { Fiber length at } 2.5 \\
\% \quad(\mathrm{~mm})\end{array}$ & $\begin{array}{c}\text { Fiber length } \\
\text { uniformity ratio (\%) }\end{array}$ & Micronaire reading & $\begin{array}{c}\text { Fiber strength (g/ } \\
\text { tex) }\end{array}$ \\
\hline 1 & \begin{tabular}{|l|}
30.85 \\
\end{tabular} & 84.95 & 4.28 & 9.75 \\
\hline 2 & 32.45 & 85.60 & 4.28 & 10.50 \\
\hline 3 & 32.43 & 85.95 & 4.23 & 10.18 \\
\hline 4 & 32.15 & 85.95 & 4.05 & 10.23 \\
\hline 5 & 32.88 & 86.03 & 3.75 & 10.15 \\
\hline 6 & 33.25 & 86.68 & 3.98 & 10.48 \\
\hline 7 & 31.45 & 86.23 & 3.98 & 9.60 \\
\hline 8 & 32.23 & 85.95 & 4.05 & 10.08 \\
\hline 9 & 32.55 & 86.38 & 4.33 & 9.63 \\
\hline 10 & 30.28 & 84.33 & 3.95 & 9.20 \\
\hline 11 & 30.40 & 84.83 & 4.13 & 9.53 \\
\hline 12 & 31.73 & 85.23 & 3.88 & 10.45 \\
\hline 13 & 33.20 & 86.15 & 4.45 & 10.45 \\
\hline 14 & 31.93 & 85.85 & 4.25 & 10.05 \\
\hline 15 & 31.13 & 85.15 & 4.00 & 9.85 \\
\hline 16 & 32.73 & 85.50 & 3.75 & 10.50 \\
\hline 17 & 33.00 & 86.05 & 4.05 & 10.75 \\
\hline 18 & 33.00 & 86.13 & 4.20 & 10.33 \\
\hline 19 & 32.50 & 85.55 & 4.20 & 10.35 \\
\hline 20 & 33.00 & 85.75 & 3.93 & 10.43 \\
\hline 21 & 31.70 & 84.88 & 4.15 & 10.03 \\
\hline 22 & 32.53 & 85.30 & 4.00 & 10.13 \\
\hline 23 & 31.93 & 85.28 & 4.30 & 9.73 \\
\hline 24 & 32.45 & 85.93 & 3.48 & 10.73 \\
\hline 25 & 33.93 & 87.08 & 3.63 & 10.58 \\
\hline 26 & 34.68 & 86.95 & 3.75 & 10.65 \\
\hline 27 & 32.88 & 85.60 & 3.75 & 10.48 \\
\hline 28 & 33.50 & 85.75 & 3.88 & 10.78 \\
\hline 29 & 32.58 & 86.60 & 3.85 & 10.28 \\
\hline 30 & 33.20 & 86.70 & 4.03 & 10.03 \\
\hline 31 & 33.80 & 85.78 & 4.08 & 10.65 \\
\hline 32 & 32.80 & 85.35 & 4.25 & 10.38 \\
\hline 33 & 30.03 & 85.53 & 4.35 & 9.48 \\
\hline 34 & 32.63 & 85.58 & 3.98 & 10.45 \\
\hline 35 & 33.25 & 85.80 & 3.65 & 10.75 \\
\hline 36 & 33.45 & 85.50 & 3.98 & 10.58 \\
\hline 37 & 32.05 & 86.63 & 4.18 & 10.00 \\
\hline 38 & 30.70 & 85.93 & 4.00 & 9.50 \\
\hline 39 & 31.40 & 85.45 & 3.90 & 10.68 \\
\hline 40 & 32.93 & 86.35 & 4.08 & 10.58 \\
\hline 41 & 33.50 & 85.98 & 3.60 & 10.60 \\
\hline 42 & 33.33 & 86.48 & 3.98 & 10.48 \\
\hline 43 & 33.80 & 87.20 & 3.45 & 10.83 \\
\hline 44 & 32.98 & 86.70 & 3.30 & 10.80 \\
\hline 45 & 33.30 & 85.55 & 4.10 & 10.15 \\
\hline 46 & 35.18 & 87.30 & 3.55 & 11.20 \\
\hline 47 & 35.03 & 87.43 & 3.88 & 10.50 \\
\hline 48 & 33.53 & 86.68 & 4.00 & 10.78 \\
\hline 49 & 31.95 & 86.33 & 3.70 & 10.48 \\
\hline 50 & 34.05 & 86.80 & 3.60 & 10.68 \\
\hline
\end{tabular}




\section{RESULTS}

Screening of genotypes for Fusarium wilt resistance:

Incidence of Fusarium wilt was used as criterion to evaluate the reactions of the tested genotypes to Fusarium wilt. The tested genotypes showed a narrow range of reaction to Fusarium wilt incidence ranging from 0 to $19.99 \%$ (Table 4). Of the tested genotypes, 54, 40 and $6 \%$ were classified as highly resistant (wilt incidence was $0 \%$ ), resistant (wilt incidence ranged from 3.33 to $6.66 \%$ ), and susceptible (wilt incidence ranged from 13.33 to $19.99 \%$ ), respectively (Table 4).

\section{Correlation analysis:}

Correlation analysis of Fusarium wilt incidence and each of agronomic and technological traits is shown in Table 5. All correlation coefficients were nonsignificant $(P>0.05)$.

Table 4. Evaluation of some cotton genotypes against Fusarium wilt (race 3) under greenhouse conditions.

\begin{tabular}{|c|c|c|}
\hline $\begin{array}{l}\text { Genotype } \\
\text { Number. }\end{array}$ & Wilt incidence $^{a} \quad(\%)$ & Disease Category $^{b}$ \\
\hline 1 & 0.00 & HR \\
\hline 2 & 0.00 & HR \\
\hline 3 & 0.00 & $\mathrm{HR}$ \\
\hline 4 & 3.33 & $\mathrm{R}$ \\
\hline 5 & 0.00 & $\mathrm{HR}$ \\
\hline 6 & 19.99 & $\mathrm{~S}$ \\
\hline 7 & 0.00 & $\mathrm{HR}$ \\
\hline 8 & 0.00 & $\mathrm{HR}$ \\
\hline 9 & 3.33 & $\mathrm{R}$ \\
\hline 10 & 3.33 & $\mathrm{R}$ \\
\hline 11 & 3.33 & $\mathrm{R}$ \\
\hline 12 & 6.66 & $\mathrm{R}$ \\
\hline 13 & 3.33 & $\mathrm{R}$ \\
\hline 14 & 0.00 & $\mathrm{HR}$ \\
\hline 15 & 3.33 & $\mathrm{R}$ \\
\hline 16 & 3.33 & $\mathrm{R}$ \\
\hline 17 & 3.33 & $\mathrm{R}$ \\
\hline 18 & 0.00 & $\mathrm{HR}$ \\
\hline 19 & 19.99 & $\mathrm{~S}$ \\
\hline 20 & 6.66 & $\mathrm{R}$ \\
\hline 21 & 0.00 & $\mathrm{HR}$ \\
\hline 22 & 0.00 & $\mathrm{HR}$ \\
\hline 23 & 0.00 & HR \\
\hline 24 & 0.00 & HR \\
\hline 25 & 0.00 & HR \\
\hline
\end{tabular}


Table 4. Cont.

\begin{tabular}{|c|c|c|}
\hline $\begin{array}{l}\text { Genotype } \\
\text { Number. }\end{array}$ & Wilt incidence $^{a}$ & Disease Category $^{b}$ \\
\hline 26 & 0.00 & HR \\
\hline 27 & 0.00 & $\mathrm{HR}$ \\
\hline 28 & 0.00 & HR \\
\hline 29 & 0.00 & HR \\
\hline 30 & 0.00 & $\mathrm{HR}$ \\
\hline 31 & 13.33 & $\mathrm{~S}$ \\
\hline 32 & 3.33 & $\mathrm{R}$ \\
\hline 33 & 0.00 & HR \\
\hline 34 & 3.33 & $\mathrm{R}$ \\
\hline 35 & 0.00 & HR \\
\hline 36 & 0.00 & $\mathrm{HR}$ \\
\hline 37 & 3.33 & $\mathrm{R}$ \\
\hline 38 & 0.00 & HR \\
\hline 39 & 6.66 & $\mathrm{R}$ \\
\hline 40 & 0.00 & HR \\
\hline 41 & 0.00 & $\mathrm{HR}$ \\
\hline 42 & 0.00 & $\mathrm{HR}$ \\
\hline 43 & 3.33 & $\mathrm{R}$ \\
\hline 44 & 6.66 & $\mathrm{R}$ \\
\hline 45 & 3.33 & $\mathrm{R}$ \\
\hline 46 & 3.33 & $\mathrm{R}$ \\
\hline 47 & 0.00 & $\mathrm{HR}$ \\
\hline 48 & 3.33 & $\mathrm{R}$ \\
\hline 49 & 3.33 & $\mathrm{R}$ \\
\hline 50 & 0.00 & HR \\
\hline
\end{tabular}

a Wilt incidence is the percentage of infected seedlings, which showed external or internal symptoms.

b Disease category is highly resistant (HR), resistant (R), and susceptible (S).

Table 5. Correlation between wilt incidence (\%) and each of agronomic and technological traits of a collection of cotton germplasm.

\begin{tabular}{|l|c|}
\hline \multicolumn{1}{|c|}{ Traits } & Correlation \\
\hline Boll weight & $-0.019^{\mathrm{a}}(0.896)^{\mathrm{b}}$ \\
\hline Seedscotton yield & $-0.149(0.302)$ \\
\hline Lint yield & $-0.128(0.374)$ \\
\hline Lint percentage & $0.016(0.914)$ \\
\hline \multicolumn{2}{|c|}{ Agronomic traits } \\
\hline Fiber length at 2.5\% & $0.038(0.793)$ \\
\hline Fiber length uniformity ratio & $-0.027(0.851)$ \\
\hline Micronaire reading & $0.049(0.736)$ \\
\hline Fiber strength & $0.152(0.292)$ \\
\hline
\end{tabular}

a Linear correlation coefficient, which measures the degree of association between wilt incidence and the tested traits.

b Probability level, all linear correlation coefficients were nonsignificant, $\mathbf{n}=\mathbf{5 0}$. 


\section{Cluster analysis:}

A phenolgram based on dissimilarity distance (DD) generated from cluster analysis of the profiles of agronomic and technological traits of the tested genotypes are presented in Fig. 1. The smaller the DD, the more closely the genotypes were related in the profiles of their traits. Four genotypes of cotton genotypes were identified by cluster analysis. The first group (the largest group) included 40 genotypes. The $2^{\text {nd }}$ group included the genotype no. 26. The $3^{\text {rd }}$ group included eight genotypes. Genotypes no. 22 was placed alone in a separate group unrelated to the other groups. The genotypes of the first group were identical in the profiles of their agronomic and technological traits $(\mathrm{DD}=0)$; however, they showed all the disease categories from highly resistant to susceptible. Therefore, grouping the isolates by cluster analysis based on their traits profiles was not related to their resistance levels.

\section{DISCUSSION}

In the present study, genotypes were screened against 50 FOV isolates from almost all cotton growing areas in Egypt. The use of such a large number of isolates is a strategy to maximize the probability that resistant genotypes identified under greenhouse conditions will maintain their resistance levels under field conditions in distinct geographic locations. On the contrary, if genotypes were screened against a limited number of isolates, they may not perform as expected due to potential presence of isolates differing in their virulence profile from those used in the greenhouse tests.

A distinctive characteristic of Fusarium wilt is the olive brown discolouration of the root and stem xylem. However, there is no consensus regarding the diagnostic importance of this vascular discolouration for evaluation of the host germplasm reaction to Fusarium wilt. For example, Armstrong and Armstrong (1978) stated that vascular discolouration is a questionable standard for judging susceptibility to wilt in seedling tests. Zink et al. (1983) found no clear relationship between the severity of external symptoms in surviving muskmelon seedlings and the extent and degree of internal vascular discolouration. On the other hand, Salgado et al. (1994) used vascular discolouration as a criterion for judging susceptibility of tepary bean (Phaseolus acutifolius Gray) seedlings to Fusarium-wilt. Osman (1996) found a highly significant correlation $(r=0.98, P<0.01)$ between external wilt symptoms and vascular discolouration of cotton seedlings (cultivar Giza 74). In the present study, we used more rigorous criteria for disease rating. According to these criteria, the seedlings were considered slightly susceptible if they showed internal discolouration even though they were free of external symptoms. Thus, the seedlings were considered resistant only if they were completely free of any internal and external symptoms. In our study, cotton genotypes were screened under very favorable conditions for FOV development. The soil was sterile, temperature was optimal most of the time, and the inoculum density was relatively high. Under these conditions, it is unlikely that any susceptible genotypes would have escaped from infection. However, one should keep in mind that evaluation in the greenhouse 
precludes identifying genotypes that may possess useful levels of field resistance to wilt. The soil infestation method, which we used for seedling inoculation, had several advantages. Assays were simple, did not damage the seedlings, and provided discriminating and reproducible disease reactions.

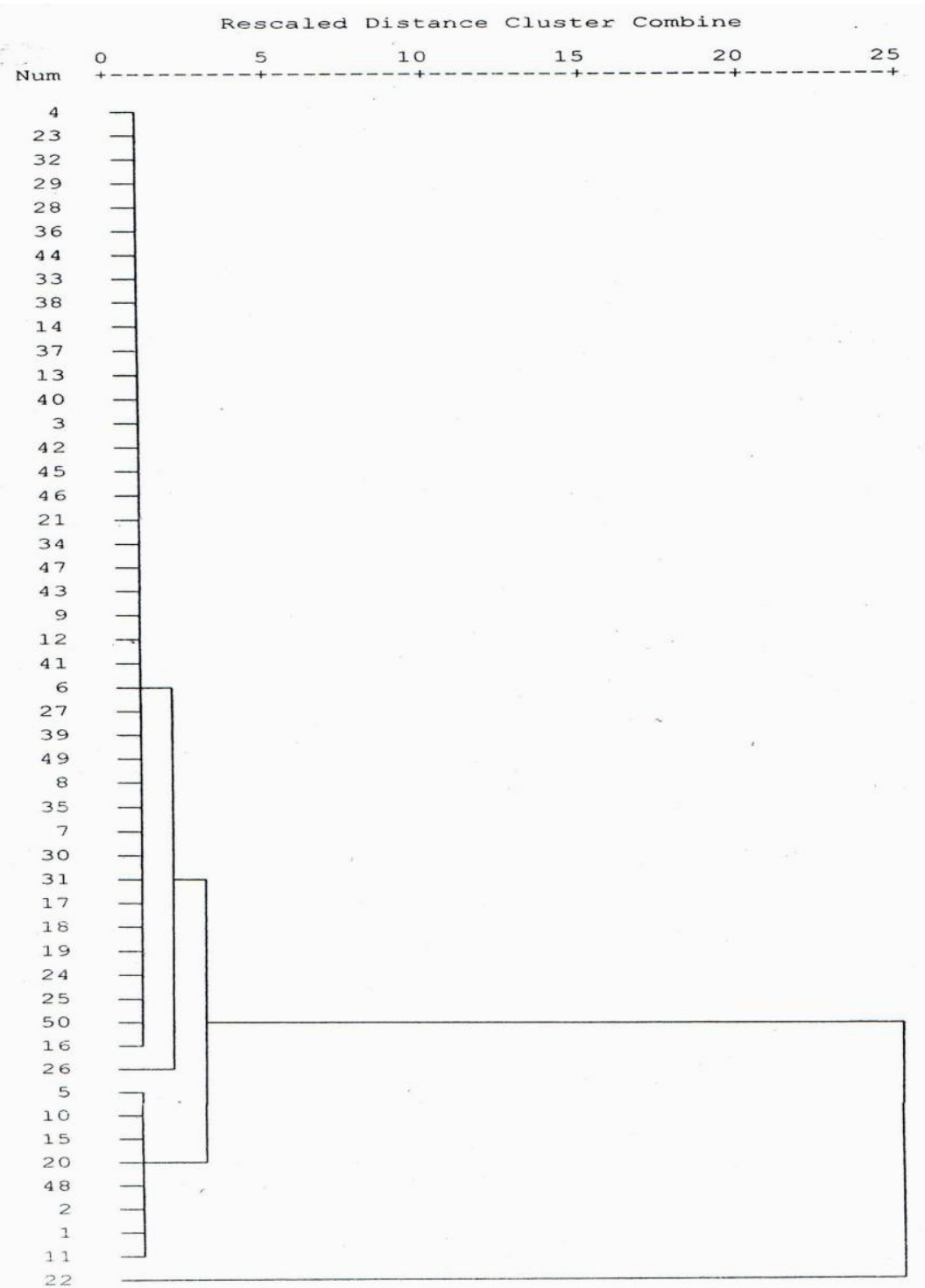

Fig. 1: Phenogram based on average linkage cluster analysis of agronomic and technological traits profiles of 50 cotton genotypes. 
Since no cotton wilt nurseries have been established in Egypt, greenhouse tests will continue to be the only reliable method for screening cotton breeding materials for Fusarium-wilt resistance. The current absence of Fusarium wilt in commercial cotton field using cultivars derived from our breeding program demonstrates the reliability of these screening procedures, which we have adopted in testing cotton genotypes for Fusarium-wilt resistance. In addition, the present work provides new and useful sources of resistance that might be employed in breeding programs aiming to develop cotton cultivars with resistance to FOV race 3 isolates.

It is well known that the type and degree of correlation between characters may facilitate or complicate selection process in breeding programs. Selection for character may result in an improvement or deterioration in other characters according to the type and degree of correlation. Hence, it was desirable to assess the type and degree of association between incidence of Fusarium wilt and some major agronomic and technological traits. The lack of correlation between wilt incidence and agronomic or technological traits, as we have demonstrated herein, indicates that breeding for Fusarium-wilt resistance will not negatively affect the quality of agronomic or technological traits of the resistant genotypes.

\section{REFERENCES}

Abd-Elsalam, K.A., M.R. Omar, Amal A. Asran, and A.A. Aly. 2009. Differential interactions among cotton genotypes and isolates of Fusarium oxysporum f.sp. Vasinfectum. Archives of Phytopathology and Plant Protection 42: $464-473$.

Aly, A.A., E.M. Hussin, M.R. Omar and A.M.A El-Samawaty. 2007. Use of protein electrophoresis to quantity resistance of cotton to Fusarium wilt disease. J. Agric. Sci. Mansoura Univ. 32: 3475 - 3488.

Aly, A.A., H.A. Eisa, M.T.M. Mansour, S.M.E. Zayed, and M.R. Omar. 2000. Resistance to Fusarium wilt disease in families of some commercial cotton cultivars. In the $19^{\text {th }}$ Conf. of the Egyptian Phytopathologyical society, 3 - 4 May 2000, Giza, Egypt. pp. 113-121.

Armstrong, G.M. and J.K. Armstrong. 1978. Formae speciales and races of Fusarium oxysporum casing wilts of the Cucurbitaceae. Phytopathology 68: $19-28$.

ASTM. 1984. American Society for Testing and Materials. D: 1447-83 and D: 1448-59.

Bakry, M.A, A.H. Sakre, O.A. Kassab, and R.H. Rizk. 1958. Infection of some cotton varieties with Fusarium and the possibility of the existence of strains of the fungus. In Proc. the $2^{\text {nd }}$ Cotton Conf. (in Arabic). Giza, Egypt.

Baxevanos, D., I.T. Tsialtas, and G. Goulas. 2013. Repeatability and stability analysis for fiber traits in Upland cotton (Gossypium hirsutum L.). Australian Journal of Crop Science 7: 1423 - 1429. 
Guo, B., S. Liu, K. Wang, X. Geng, X. Zhang, J. Geng and C. Zhao. 2013. Correlation analysis of seed kernel oil content and major economic traits in cotton (Gossypium hirsutum). Cotton Science 25: $365-371$.

Hillocks, R.J. 1984. Production of cotton varieties with resistance to Fusarium wilt with special reference to Tanzania. Tropical Pest Management 30: $234-246$.

McFadden, H., D. Beasley, and C.L. Brubaker. 2004. Assessment of Gossypium sturtianum and $G$. australe as potential sources of Fusarium-wilt resistance to cotton. Euphytica 138: $61-72$.

Netzer, D.Y. Tal, A. Marani, and C. Weintall. 1985. Resistance of interspecific cotton hybrids (Gossypium Hirsutum x G. barbadense - containing G. harknessii cytoplasm) to Fusarium wilt. Plant Dis. 69: $312-313$.

Osman, Eman, A.M. 1996. Studies on the interrelationships among some Fusarium species with special reference to their pathogenicity on cotton. Ph.D. Thesis, Cairo Univ., Cairo, 125 pp.

Said, J.I, Z. Lin, X. Zhang, M. Song, and J. Zhang. 2013. Comprehensive meta QTL analysis for fiber quality, yield, yield related and morphological traits, drought tolerance, and disease resistance in tetraploid cotton. BMC Genomics. 14: 776.

Salgado, M.O., H.F. Schwartz, and M.A. Pastor-Corrales (1994). Resistance to Fusarium oxysporum f. sp. Phaseolin in tepary beans (Phaseolus acutifolius). Plant Dis. 78: $357-360$.

Sundaram, V. 1979. Handbook of Methods of Tests for Cotton Fibers, Yarn, and Fabrics. Indian Council of Agric. Res., P 71 - 76.

Ulloa, M., R.B. Hutmacher, R.M. Davis, S.D. Wright, R. Percy, and B. Marsh. 2006. Breeding for Fusarium wilt race 4 resistance in cotton under field and greenhouse conditions. The Journal of Cotton Science 10: $114-127$.

Watkins, G.M. ed. 1981. Compendium of Cotton Diseases. The American Phytopathological Society. St. Paul, MN.. 87P.

Wu, Z., Y. Yang, X. Liu, and Q. Wang. 2004. Cotton yield and fiber quality affected by Fusarium wilt. Cotton Science 16: $236-239$.

Zink, F.W., W.D. Guber, and R.G. Grogan. 1983. Reaction of muskmelon germplasm to inoculation with Fusarium oxysporum f. sp. melonis race 2. Plant Dis. 67: 1251 - 1255. 


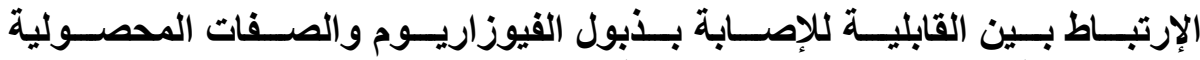

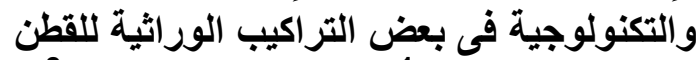

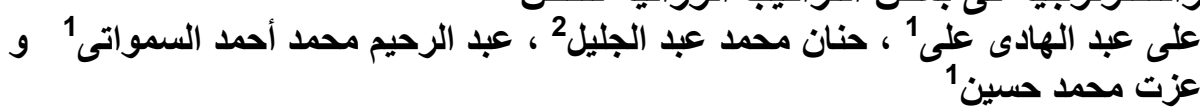
1. معهة بحوث أمراض النباتات ـ مركز البحوث الزراعية ــ الجيزة ــ مصر. 2. معهد بحوث القطن - مركز البحوث الزراعية ــ الجيزة ــ مصر.

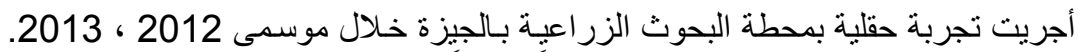

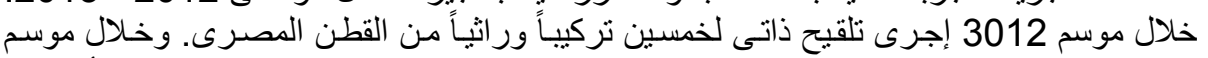

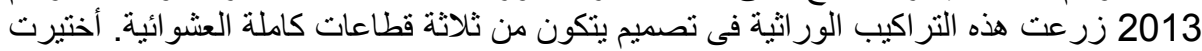

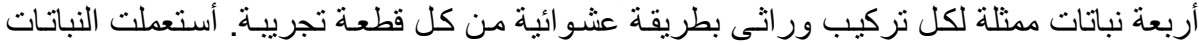

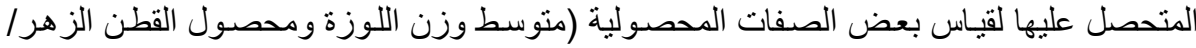

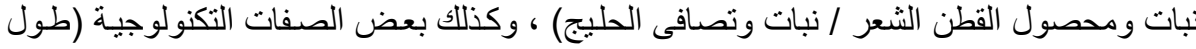

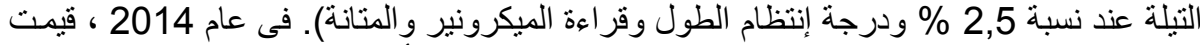

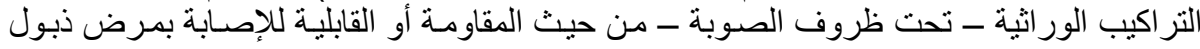

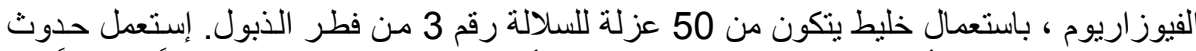

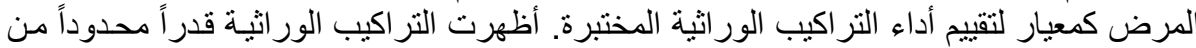

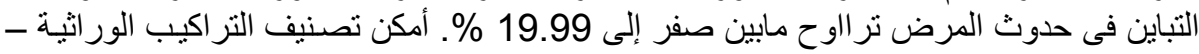

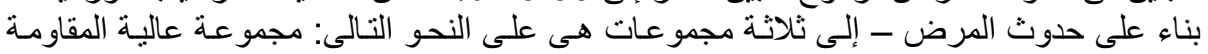

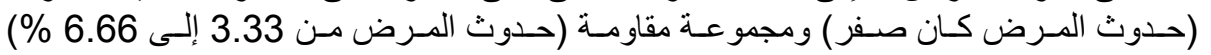

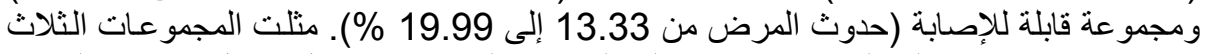

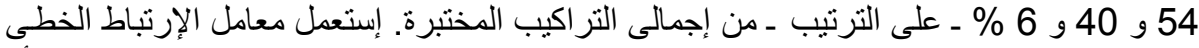

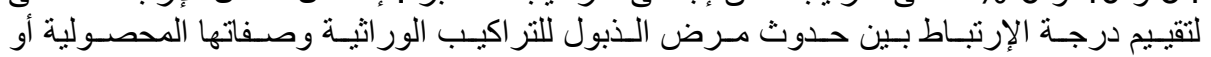

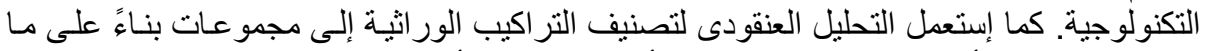

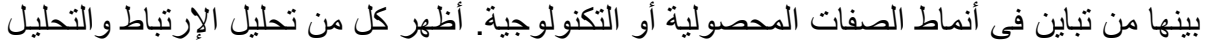

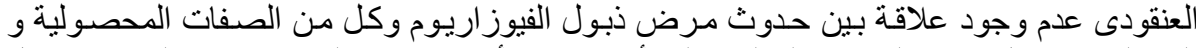

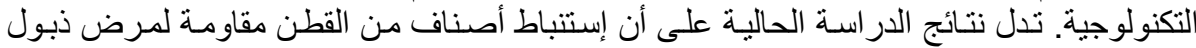

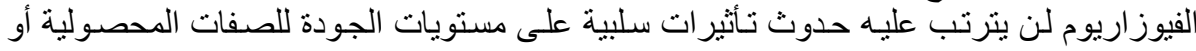

